\title{
Treatment of venous ulcers with growth factors: systematic review and meta-analysis
}

\author{
Tratamento de úlceras venosas com fatores de crescimento: revisão sistemática e metanálise \\ Tratamiento de úlceras venosas confactores de crecimiento: revisión sistemática y metanálisis
}

Magali Rezende de Carvalho'
ORCID: 0000-0002-2261-5570
Isabelle Andrade Silveira'
ORCID: 0000-0002-5458-0456

Beatriz Guitton Renaud Baptista de Oliveira' ORCID: 0000-0001-7494-7457

'Universidade Federal Fluminense, Escola de Enfermagem Aurora de Afonso Costa. Niterói, Rio de Janeiro, Brazil.

How to cite this article: Carvalho MR, Silveira IA, Oliveira BGRB. Treatment of venous ulcers with growth factors: systematic review and metaanalysis. Rev Bras Enferm [Internet]. 2019;72(1):200-10. DOI: http://dx.doi.org/10.1590/0034-7167-2017-0865

Corresponding Author: Magali Rezende de Carvalho E-mail:magalirecar@gmail.com

Submission: 12-11-2017 Approval: 06-08-2018

\section{ABSTRACT}

Objective: To identify evidence about the effects of growth factor application on venous ulcer healing. Method: Systematic review and meta-analysis, including Randomized Clinical Trials. Searches: Ovid MEDLINE, EMBASE, CINAHL, Cochrane CENTRAL, LILACS, Web of Science, Digital Library of Theses and Dissertations; Google Scholar and list of references. Results: 802 participants were recruited from the 10 included studies: 472 in the intervention group (growth factors) and 330 as control. The relative risk for the complete healing outcome was 1.06 [95\% Cl 0.92-1.22], $p=0.41$. Participants who received Platelet-Rich Plasma and Epidermal Growth Factor showed a slight tendency to achieve complete healing, but without statistical relevance ( $p$ $<0.05$ ). Most of the studies were classified as moderate risk of bias. Conclusion: The effect of the application of growth factors for complete healing in venous ulcers is not clear, and clinical trials with methodological quality are required for more accurate recommendations.

Descriptors: Intercellular Signaling Peptides and Proteins; Varicose Ulcer; Healing; Evidence-Based Nursing; Nursing Care.

\section{RESUMO}

Objetivo: Identificar evidências acerca dos efeitos da aplicação de fatores de crescimento na cicatrização de úlceras venosas. Método: Revisão sistemática e metanálise, incluindo Ensaios Clínicos Randomizados. Buscas: Ovid MEDLINE, EMBASE, CINAHL, Cochrane CENTRAL, LILACS, Web of Science, Biblioteca Digital de Teses e Dissertações; Google Acadêmico e lista de referências. Resultados: 802 participantes foram recrutados pelos 10 estudos incluídos: 472 no grupo intervenção (fatores de crescimento) e 330 como controle. O risco relativo para o desfecho de cicatrização completa foi de 1,06 [IC95\% 0,92-1,22], $\mathrm{p}=0.41$. Os participantes que receberam Plasma Rico em Plaquetas e Fator de Crescimento Epidérmico apresentaram uma ligeira tendência a alcançar cicatrização completa, porém sem relevância estatística $(p<0.05)$. A maioria dos estudos foi classificada como moderado risco de viés. Conclusão: 0 efeito da aplicação de fatores de crescimento para cicatrização completa em úlceras venosas não está claro, sendo necessários ensaios clínicos com qualidade metodológica para recomendações mais precisas.

Descritores: Peptídeos e Proteínas de Sinalização Intercelular; Úlcera Varicosa; Cicatrização; Enfermagem Baseada em Evidências; Cuidados de Enfermagem.

\section{RESUMEN}

Objetivo: Identificar evidencias acerca de los efectos de la aplicación de factores de crecimientoenlacicatrización de úlceras venosas. Método: Revisión sistemática y metanálisis, incluyendo Ensayos Clínicos aleatorizados. Búsquedas: Ovid MEDLINE, EMBASE, CINAHL, Cochrane CENTRAL, LILACS, Web of Science, Biblioteca Digital de Tesis y Disertaciones; Google Académico y lista de referencias. Resultados: 802 participantes fueron reclutados por los 10 estudios incluidos: 472 en el grupo intervención (factores de crecimiento) y 330 como control. El riesgo relativo para el desenlace de cicatrización completa fue de 1,06 [IC95\% 0,92-1,22], $p=0.41$. Los participantes que recibieron Plasma Rico en Plaquetas y Factor de Crecimiento Epidérmico presentaron una ligera tendencia a alcanzar una cicatrización completa, pero sin relevancia estadística ( $p$ $<0.05$ ). La mayoría de los estudios se clasificaron como moderado riesgo de sesgo. Conclusión: El efecto de la aplicación de factores de crecimiento para cicatrización completa en úlceras venosas no está claro, siendo necesarios ensayos clínicos con calidad metodológica para recomendaciones más precisas.

Descriptores: Péptidos y Proteínas de Señalización Intercelular; Úlcera Varicosa; Cicatrización de Heridas; Enfermería Basada en la Evidencia; Cuidados de Enfermería. 


\section{INTRODUCTION}

Tissue repair involves a series of complex, dynamic and sequential interactions involving cells of the epidermis, dermis, extracellular matrix, and plasma proteins ${ }^{(1)}$. The growth factors are responsible for inducing simultaneous effects on several cell types and provoking a series of biological functions in several tissues, positively interfering in the healing process, which makes its use an attractive therapeutic possibility in several segments of Medicine ${ }^{(2-3)}$.

Growth factors act in a way to inhibit or stimulate the target cell's gene expression in the wound. By transmitting modulatory signals, growth factors regulate stimulatory and inhibitory growth processes, such as proliferation, differentiation, migration, and adhesion ${ }^{(4)}$. In addition, they also act to promote cell chemotaxis, being able to induce the migration of several cells, besides stimulating the angiogenesis and the synthesis of the extracellular matrix ${ }^{(2)}$.

Thus, the whole process involving tissue repair occurs continuously and dynamically, dictated by numerous growth factors and other cytokines, such as tumor necrosis factor (TNF-a) and interleukins $s^{(5)}$. When there is an imbalance between pro and antiinflammatory cytokines, the wound is chronified, which remains in a persistent and uncontrolled inflammatory phas ${ }^{(6)}$. At the same time, there is a low mitogenic activity, as well as the presence of fibroblasts with premature senescence and degradation of the cell matrix ${ }^{(6)}$. Insufficient bioavailability of growth factors, either by decreased synthesis and/or excessive degradation, is a hallmark of chronic wounds $s^{(4,7)}$. Therefore, the longer the duration of the ulcer, the worse its prognosis in relation to healing ${ }^{(8)}$.

The application of growth factors has been cited as a favoring factor for the tissue repair of chronic ulcers of different etiologies, thus enabling the individual to return to his or her habitual activities ${ }^{(7)}$. Considering the prevalence of venous ulcers, high recurrence rates and long treatment, it is mandatory to seek alternative therapies that aid tissue repair and promote the return of the affected individual to their normal daily activities in the shortest time possible ${ }^{(9)}$.

A previous search for evidence of the effectiveness of growth factors performed in the major electronic search databases for systematic reviews (Cochrane Library, Joanna Briggs Institute Library, Center for Review and Dissemination (CRD) of York University and PubMed) revealed little scientific production about growth factors for the treatment of venous ulcers. Two systematic reviews addressing the efficacy of growth factors (present in Platelet-Rich Plasma - PRP) on chronic ulcers ${ }^{(10-11)}$; and two others that addressed the efficacy of PRP in diabetic ulcers ${ }^{(12-13)}$. However, none of the reviews evaluated growth factors alone. In addition, only one of them evaluated the application of PRP in venous ulcers ${ }^{(10)}$. However, this review does not contemplate the evaluation of other growth factors, in addition to having included studies only until January 2015. In addition, two reviews (12-13) $^{(20)}$ contemplate studies only with diabetic ulcers, whose etiology and treatment approach considerably differs from venous ulcers.

In view of the above, the treatment of venous ulcers with products or preparations containing growth factors should be investigated for its efficacy.

\section{OBJECTIVE}

To identify evidence in the scientific literature about the effects of the application of growth factors on venous ulcers healing, compared to other therapies.

\section{METHOD}

This is a systematic review with meta-analysis, according to the recommendations proposed by the Cochrane Collaboration ${ }^{(14)}$.

The research question, elaborated according to the P.I.C.O. strategy ${ }^{(14)}$, was thus determined: What is the effect of the application of growth factors on venous ulcers healing compared to other therapies?

The clinical outcome evaluated was the total number of healed ulcers. Inclusion criteria were: Randomized Clinical Trials (RCTs) that address the use of growth factors associated or not with other therapies for the treatment of venous ulcers; studies covering the total number of healed ulcers. Exclusion criteria: ongoing studies and research protocols; articles that associate growth factors with the skin graft; studies that included ulcers of multiple etiologies without subgroup analysis.

The search in the electronic databases took place on October 6 , 2017, by two independent reviewers. The following databases were consulted: Ovid MEDLINE (R) 1946 to 2017 Sept Week 4; EMBASE 1974 to 2017 Oct 5; Ebsco CINAHL Plus with Full Text -1937-2017, Cochrane CENTRAL, LILACS and Web of Science - 1950-2017.

The search for studies originating from other sources occurred in September and October 2017. The repository of theses and dissertations was accessed nationally - Brazilian Digital Library of Theses and Dissertations, Google Scholar, list of references of included studies, as well as the list of articles related to each article included, through the PubMed platform. There was no restriction on language or year of publication.

Thesauri MeSH, DeCs, ENTREE and Cinahl Titles, as well as appropriate free terms, were rescued for the construction of specific search strategies for each database. The search strategy in the MEDLINE database via Ovid was elaborated from the Cochrane strategy of high sensitivity for identification of Randomized Clinical Trials ${ }^{(14)}$. The thesauri and free terms were adapted to the elaboration of the other strategies according to the specificities of each database. The strategies used are listed in Chart 1.

$\mathrm{MeSH}$ and DeCs thesauri were used to search other sources, as well as free terms combined with the Boolean operators AND and OR.

After exclusion of the duplicates, the studies were independently analyzed by two reviewers in relation to the title and abstract. The relevant studies have been fully recovered and the eligibility criteria. The degree of agreement between the two reviewers was established by the Kappa measure (Biostat ${ }^{\circ} 5.0$ ), and the index reached was 0.83 . Disagreements were discussed at a consensus meeting and disagreements were resolved with the collaboration of the reviewer and senior researcher.

The bias risk assessment was performed according to the recommendations of the Cochrane Collaboration ${ }^{(14)}$. The studies were evaluated in six domains (selection-sequence randomization bias, selection bias - allocation stealth, performance bias-masking of participants and investigator, detection bias - evaluator masking, friction bias - incomplete results at high loss rates, with losses of 
up to $20 \%$ being considered: low,> $20 \% \leq 30 \%$ : moderate,> $30 \%$ : high risk; reporting bias - selective reporting, incomplete data publication, e.g., missing means and/or Standard Deviation for the rated outcome. Each study was classified as low, moderate or high risk of bias according to the domains evaluated. In order to evaluate the masking domain of the researchers and participants, it was considered low risk both the double-blind declared studies and the non-blinded studies in this question ${ }^{(14)}$. To evaluate the mastery domain of the evaluator was considered low risk only when the author declared the blinding in this item ${ }^{(16)}$. The GRADE system $^{(14,17)}$ (Grading of Recommendations Assessment, Development and Evaluation) was used to evaluate the quality of evidence.

The relative risk was calculated for the variables, considering a Confidence Interval of $95 \%$. Additional analyzes were performed by subgroups by type of growth factors and their relative risk for the outcome of complete healing. The heterogeneity was evaluated statistically using the Chi-square test and considering fixed-effect analysis when heterogeneity less than $50 \%$. To perform the meta-analysis, the statistical software Review Manager (RevMan) version 5.3 was used.
This review followed the recommendations proposed by PRISMA (Preferred Reporting Items for Systematic Reviews and Meta-Analyzes). The present review presents some updated results of a more comprehensive review, whose protocol is registered in the PROSPERO database (International Prospective Register of Ongoing Systematic Reviews) under the number CRD42016038390.

\section{RESULTS}

311 reports were retrieved after the exclusion of the duplicates and the application of the eligibility criteria. 9 articles containing results from 10 studies were included in this review, as shown in the flowchart (Figure 1).

Chart 2 presents the characterization of the studies included in the analysis, as well as the bias risk assessment of each study.

The country that most produced research involving growth factors was the United States, responsible for more than half of the studies included in the analysis; all studies were published in the English language.

Chart 1 - Search strategies employed in their respective databases

\begin{tabular}{|c|c|}
\hline Database & Search strategies \\
\hline $\begin{array}{l}\text { Ovid } \\
\text { MEDLINE(R) } \\
\text { and EMBASE }\end{array}$ & $\begin{array}{l}\text { (((randomized controlled trial.pt or controlled clinical trial.pt or randomized.ab. OR placebo.ab. OR clinical trial as topic.sh. ORran- } \\
\text { domly.ab. ORtrial.ti.) not (exp animals/ not humans.sh.)) and (platelet derived endothelial cell growth factor/ OR platelet derived } \\
\text { growth factor/ OR platelet derived growth factor a/ OR platelet derived growth factor ab/ OR platelet derived growth factor ab/ } \\
\text { OR platelet derived growth factor b/ OR recombinant platelet derived growth factor/ OR recombinant cytokine/ OR recombinant } \\
\text { growth factor/ ORbecaplermin/ OR recombinant fibroblast growth factor/ OR recombinant growth factor/ OR recombinant kerati- } \\
\text { nocyte growth factor/ ORsprifermin/ ORvelafermin/ OR recombinant fibroblast growth factor 19/ OR transforming growth factor/ } \\
\text { OR transforming growth factor alpha/ OR transforming growth factor beta/ OR recombinant transforming growth factor.mp. } \\
\text { ORexp epidermal growth factor/ ORexp recombinant epidermal growth factor/ ORexp fibroblast growth factor/ ORexp platelet- } \\
\text { rich plasma/ OR platelet-rich plasma.ab. OR autologous platelet-rich gel.mp. OR autologous platelet-rich plasma.mp.) and (exp leg } \\
\text { ulcer/ OR venous leg ulcer*.ab. OR venous ulcer*.ab. OR varicose ulcer.mp.)) }\end{array}$ \\
\hline CINAHL & 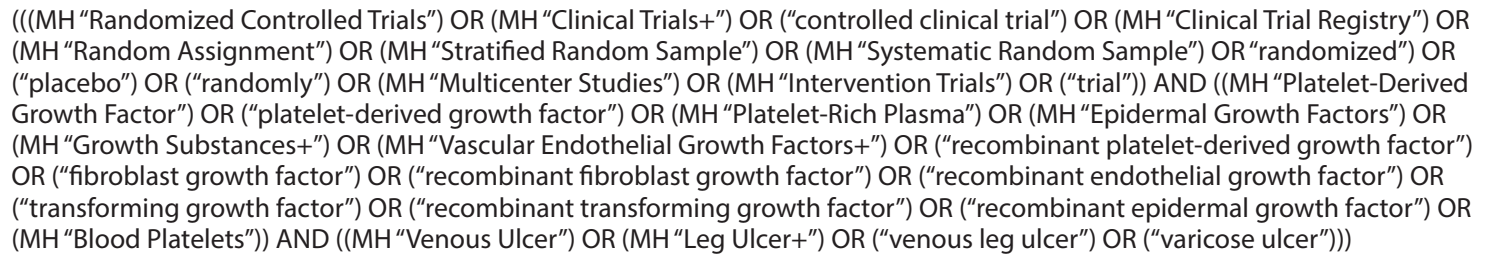 \\
\hline $\begin{array}{l}\text { Cochrane } \\
\text { CENTRAL }\end{array}$ & $\begin{array}{l}\text { (((MeSH descriptor: [Intercellular Signaling Peptides and Proteins] explode all trees) OR (MeSH descriptor: [Platelet-Rich Plasma] } \\
\text { explode all trees) OR (MeSH descriptor: [Platelet-Derived Growth Factor] explode all trees) OR (MeSH descriptor: [Epidermal } \\
\text { Growth Factor] explode all trees) OR (MeSH descriptor: [Vascular Endothelial Growth Factors] explode all trees) OR (MeSH descrip- } \\
\text { tor: [Fibroblast Growth Factors] explode all trees) OR (MeSH descriptor: [Transforming Growth Factors] explode all trees) OR (re- } \\
\text { combinant growth factor*:ab,ti (Word variations have been searched)) AND ((MeSH descriptor: [Varicose Ulcer] explode all trees) } \\
\text { OR (venous leg ulcer*:ab,ti (Word variations have been searched)) OR (venous ulcer*:ab,ti (Word variations have been searched))) }\end{array}$ \\
\hline \multirow[t]{4}{*}{ LILACS } & $\begin{array}{l}\text { ((mh:" "Platelet-Rich Plasma" OR tw:growth factor\$ OR tw:recomb\$ growth factor OR mh:"Platelet-derived growth factor" OR } \\
\text { mh:"epidermal growth fator" OR mh:"transforming Growth Factors" OR mh:"Fibroblast Growth Factors" OR mh:"Vascular Endotheli- } \\
\text { al Growth Factor" OR tw:plasma ricoemplaqueta\$ OR tw:fator\$ de crescimento\$ OR tw: Factor\$ de Crecimiento\$) AND (mh:"varicose } \\
\text { ulcer" OR tw:venous ulcer\$ OR tw:venous leg ulcer\$ OR tw: úlceravenosa)) }\end{array}$ \\
\hline & $\begin{array}{l}\text { ((mh:Platelet-Rich Plasma OR tw:growth factor\$ OR tw:recomb\$ growth factor OR tw:plasmaricoemplaqueta\$ OR tw:fator\$ de cresci- } \\
\text { mento\$ OR tw: Factor\$ deCrecimiento\$) AND (mh:varicose ulcer OR tw:venous ulcer\$ OR tw:venous leg ulcer\$ OR tw: úlceravenosa)) }\end{array}$ \\
\hline & $\begin{array}{l}\text { ((tw:growth factors OR tw:fator\$ de crescimento OR tw:factor\$ de crescimiento) AND (mh:varicose ulcer OR tw:venous ulcer OR } \\
\text { tw:venous leg ulcer OR tw:úlceravenosa OR tw:úlceravaricosa)) }\end{array}$ \\
\hline & $\begin{array}{l}\text { ((growth factors OR fator\$ de crescimento OR factor\$ decrescimiento) AND (varicose ulcer OR venous ulcer OR venous leg ulcer OR } \\
\text { úlceravenosa)) }\end{array}$ \\
\hline Web of Science & $\begin{array}{l}\text { (TS=(Recombinant Fibroblast Growth Factor OR Recombinant Growth Factor OR Recombinant Keratinocyte Growth Factor OR } \\
\text { Recombinant Fibroblast Growth Factor OR Transforming Growth Factor OR Epidermal Growth Factor OR Recombinant Epidermal } \\
\text { Growth Factor OR Fibroblast Growth Factor OR Platelet-Rich Plasma OR Autologous platelet-rich gel OR Platelet-Derived Growth } \\
\text { Factor OR Vascular Endothelial Growth Factor) AND TS=(varicose ulcer* OR Venous ulcer* Varicose wound* OR venous leg ulcer) } \\
\text { AND TS=(clinical trial OR random* OR trial OR randomized clinical trial)) }\end{array}$ \\
\hline
\end{tabular}

Note: PT (publication type); AB (abstract word); SH. (MESH descriptor); ti.(title word); MP. (text search); MH (Major and Minor Subject Headings -MESH or DECS controlled vocabulary); MM (Major Subject Headings - controlled vocabulary); TW(text word), TS (topic search). 


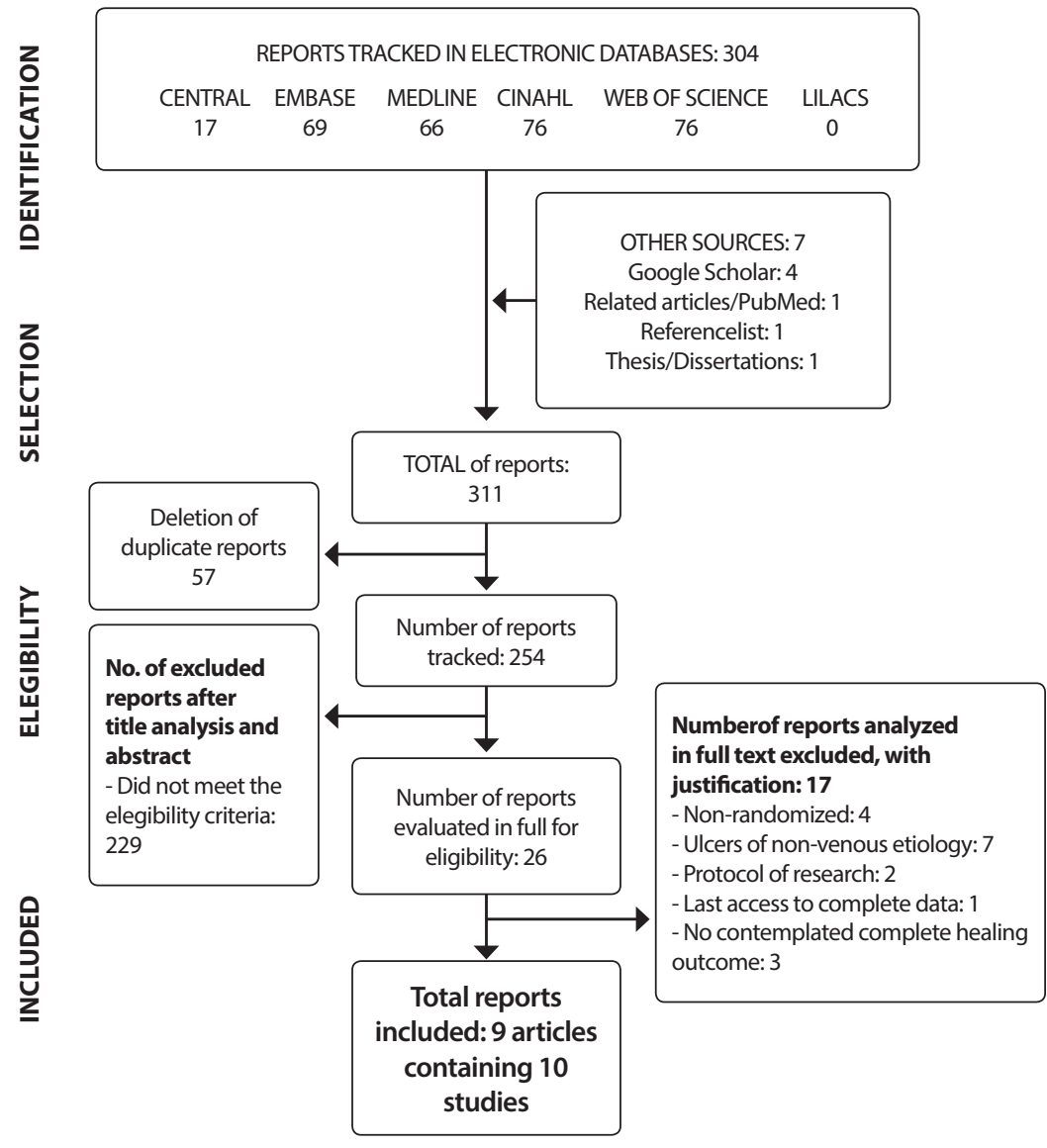

Note: *9 reports included, however, 1 report reports results from 2 different studies, therefore, 10 studies were analyzed.

Figure 1 - Flowchart of search and selection of studies
Eight hundred and two participants with venous ulcers were recruited to participate in the 10 studies included in this review. The majority of the participants received compression therapy as adjunctive therapy, having only one study ${ }^{(18)}$ that did not use compression bandaging. 472 participants were treated with growth factors and 330 received standard treatment and/or placebo. 236 (50\%) healed completely in the"treated with growth factors"group and 151 (45.75\%) in the"control"group.

With the exception of 1 study ${ }^{(18)}$, all of them considered chronic venous ulcers with more than 6 months of evolution at admission, with a mean ulcer duration of 14.32 months (SD \pm 14.11 ) in the group that received growth factors and 16.04 months $(S D \pm 19.97)$ in the control group. In relation to the size, the group that received growth factors had ulcers with a mean of $8,722 \mathrm{~cm}^{2}(S D \pm 2.93)$ and the control group, a mean of $8,504 \mathrm{~cm}^{2}(\mathrm{SD} \pm 4.50)$.

Only study I ${ }^{(25)}$ was classified as low risk of bias in all domains. The J study ${ }^{(26)}$ was classified as high risk for not reporting its results completely. Studies A, B, C, D, E, F, G and $\mathrm{H}$ were classified as being moderate risk of bias due to failures in the description of randomization method and/ or secrecy of allocation or by failures in the description of masking applied in the research ${ }^{(18-24)}$.

Chart 3 presents the description of the technologies evaluated, outcomes of interest and time of follow-up of each study.

Chart 2 - Distribution of studies according to the authors, growth factor tested, number of participants, frequency of application, masking and risk of bias

\begin{tabular}{|c|c|c|c|c|c|c|c|}
\hline \multirow{2}{*}{$\begin{array}{l}\text { Study's } \\
\text { ID }\end{array}$} & \multirow{2}{*}{$\begin{array}{l}\text { Authors and } \\
\text { year of publication }\end{array}$} & \multirow{2}{*}{ Growth Factor tested } & \multicolumn{2}{|c|}{ Number of Participants } & \multirow{2}{*}{$\begin{array}{l}\text { Frequency of } \\
\text { Application }\end{array}$} & \multirow{2}{*}{ Masking } & \multirow{2}{*}{ Risk of Bias } \\
\hline & & & Test & Control & & & \\
\hline A & Somani et al, $2017^{(18)}$ & PRP & 9 & 6 & $1 \mathrm{X}$ a week & Does notreport & Moderate \\
\hline B & Aguirre et al, $2015^{(19)}$ & PRP & 12 & 11 & $1 \mathrm{X}$ a week & Does notreport & Moderate \\
\hline C & Robson et al, 2004 & KGF & $\begin{array}{l}60 \mu g-123 \\
120 \mu g-112\end{array}$ & 117 & Exchange: $2 \mathrm{X}$ a week & Double-blind & Moderate \\
\hline D & Senet et al, $2003^{(21)}$ & PRP & 8 & 7 & $3 \mathrm{X}$ a week & Double-blind & Moderate \\
\hline $\mathrm{E}$ & Wieman-1a, 2001 (22) & PDGF & 35 & 36 & Exchange: daily & Double-blind & Moderate \\
\hline $\mathrm{F}$ & Wieman-1b, 2001 $1^{(22)}$ & PDGF & 32 & 32 & Exchange: $2 \mathrm{X}$ week & Double-blind & Moderate \\
\hline G & Robson et al, 2001(23) & KGF & $\begin{array}{l}20 \mu g-32 \\
60 \mu g-32\end{array}$ & 31 & Exchange: $2 \mathrm{X}$ week & Double-blind & Moderate \\
\hline $\mathrm{H}$ & Stacey et al, $2000^{(24)}$ & PRP & 42 & 44 & Exchange: $2 \mathrm{X}$ week & Double-blind & Moderate \\
\hline I & Robson et al, $1995^{(25)}$ & TGF- $\beta$ & 12 & $\begin{array}{l}\text { Control 1- } 12 \\
\text { Control 2-12 }\end{array}$ & Exchange: $3 \mathrm{X}$ week & Blindevaluator & Low \\
\hline
\end{tabular}


Chart 2 (concluded)

\begin{tabular}{|c|c|c|c|c|c|c|c|}
\hline \multirow{2}{*}{$\begin{array}{l}\text { Study's } \\
\text { ID }\end{array}$} & \multirow{2}{*}{$\begin{array}{l}\text { Authors and } \\
\text { year of publication }\end{array}$} & \multirow{2}{*}{ Growth Factor tested } & \multicolumn{2}{|c|}{ Number of Participants } & \multirow{2}{*}{$\begin{array}{c}\text { Frequency of } \\
\text { Application }\end{array}$} & \multirow{2}{*}{ Masking } & \multirow{2}{*}{ Risk of Bias } \\
\hline & & & Test & Control & & & \\
\hline \multirow[t]{2}{*}{$J$} & Falanga et al, 1992(26) & EGF & 23 & 22 & Exchange: $2 \mathrm{X}$ dia & Double-blind & High risk \\
\hline & Total & & 472 & 330 & & & \\
\hline
\end{tabular}

Note: PRP: Platelet-Rich Plasma; KGF: Keratinocytes Growth Factor; PDGF: Platelet Derived Growth Factor; TGF- $\beta$ : Transforming Growth Factor Beta; EGF: Epidermal Growth Factor.

Chart 3 - Description of the technologies evaluated, outcomes and follow-up time of each study included in the review

\begin{tabular}{|c|c|c|c|c|c|}
\hline \multirow{2}{*}{$\begin{array}{l}\text { Study's } \\
\text { ID }\end{array}$} & \multirow{2}{*}{ Intervention } & \multirow{2}{*}{ Control } & \multicolumn{2}{|c|}{ Complete Healing } & \multirow{2}{*}{ Follow-up Time } \\
\hline & & & Intervention & Control & \\
\hline$A$ & PRP & Saline Solution & $5 / 9$ & $0 / 6$ & 4 weeks \\
\hline B & $\begin{array}{c}\mathrm{PRP}+ \\
\text { compression therapy }\end{array}$ & $\begin{array}{l}\text { Silicone dressing + } \\
\text { compression therapy }\end{array}$ & $5 / 12$ & $0 / 11$ & 8 weeks \\
\hline $\mathrm{C}$ & $\begin{array}{l}\text { KGF } 60 \mathrm{mg} \text { or } 120 \mathrm{mg}+ \\
\text { compression therapy }\end{array}$ & Placebo + compression therapy & $\begin{array}{c}60 \mu-72 / 123 \\
120 \mu g-58 / 112\end{array}$ & $72 / 117$ & 26 weeks \\
\hline $\mathrm{D}$ & $\begin{array}{c}\text { FrozenPRP }+ \\
\text { compression therapy }\end{array}$ & $\begin{array}{c}\text { Saline Solution + } \\
\text { compressiontherapy }\end{array}$ & $1 / 8$ & $1 / 7$ & 12 weeks \\
\hline$E$ & $\begin{array}{c}\text { PDGF + } \\
\text { compression therapy }\end{array}$ & $\begin{array}{c}\text { Placebo gel }+ \\
\text { compression therapy }\end{array}$ & $12 / 35$ & $12 / 36$ & 16 weeks \\
\hline $\mathrm{F}$ & $\begin{array}{c}\text { PDGF + } \\
\text { compression therapy }\end{array}$ & $\begin{array}{c}\text { Placebo gel }+ \\
\text { compression therapy }\end{array}$ & $18 / 32$ & $14 / 32$ & 16 weeks \\
\hline G & $\begin{array}{l}\text { KGF } 20 \text { mg or } 60 \mathrm{mg}+ \\
\text { compression therapy }\end{array}$ & Placebo + compression therapy & $\begin{array}{l}20 \mu g-10 / 32 \\
60 \mu g-12 / 32\end{array}$ & $9 / 31$ & 12 weeks \\
\hline $\mathrm{H}$ & $\begin{array}{c}\text { FrozenPRP }+ \\
\text { compression therapy }\end{array}$ & $\begin{array}{l}\text { PBS Solution+ } \\
\text { compressiontherapy }\end{array}$ & $33 / 42$ & $34 / 44$ & 36 weeks \\
\hline I & $\begin{array}{c}\text { Collagen matrix } \\
\text { containing TGF- } \beta+ \\
\text { compression therapy }\end{array}$ & $\begin{array}{c}\text { Controle 1: Matriz de colágeno + } \\
\text { terapia compressiva } \\
\text { Controle 2: gaze petrolada }+ \\
\text { terapia compressiva }\end{array}$ & $4 / 12$ & $\begin{array}{l}\text { Control } 1-4 / 12 \\
\text { Control } 2-3 / 12\end{array}$ & 6 weeks \\
\hline$J$ & $\begin{array}{c}\text { EGF + compression } \\
\text { therapy }\end{array}$ & Placebo + compression therapy & $6 / 23$ & $2 / 22$ & 10 weeks \\
\hline & Total & & $236 / 472$ & $151 / 330$ & \\
\hline
\end{tabular}

Note: PRP: Platelet-Rich Plasma; PBS: Phosphate Buffered Saline, KGF: Keratinocytes Growth Factor; PDGF: Platelet Derived Growth Factor; TGF- $\beta$ : Transforming Growth Factor Beta; EGF: Epidermal Growth Factor.

Ten studies were included in a meta-analysis for the overall complete healing outcome. We also performed analyzes by subgroups of growth factors to verify the effectiveness of each type of growth factor presented.

The forest plot shows the relative risk, $95 \%$ Confidence Intervals and Risk Classification of studies bias in a global manner, and also by the growth factor involved (Figure 2).
The overall complete healing rate was similar between the groups that received growth factors and the control group $(p=0.41)$. Participants treated with PRP and EGF presented a slight tendency to achieve complete healing, but without statistical relevance. Most of the studies presented moderate quality of evidence in the domains related to the randomization and allocation process. 


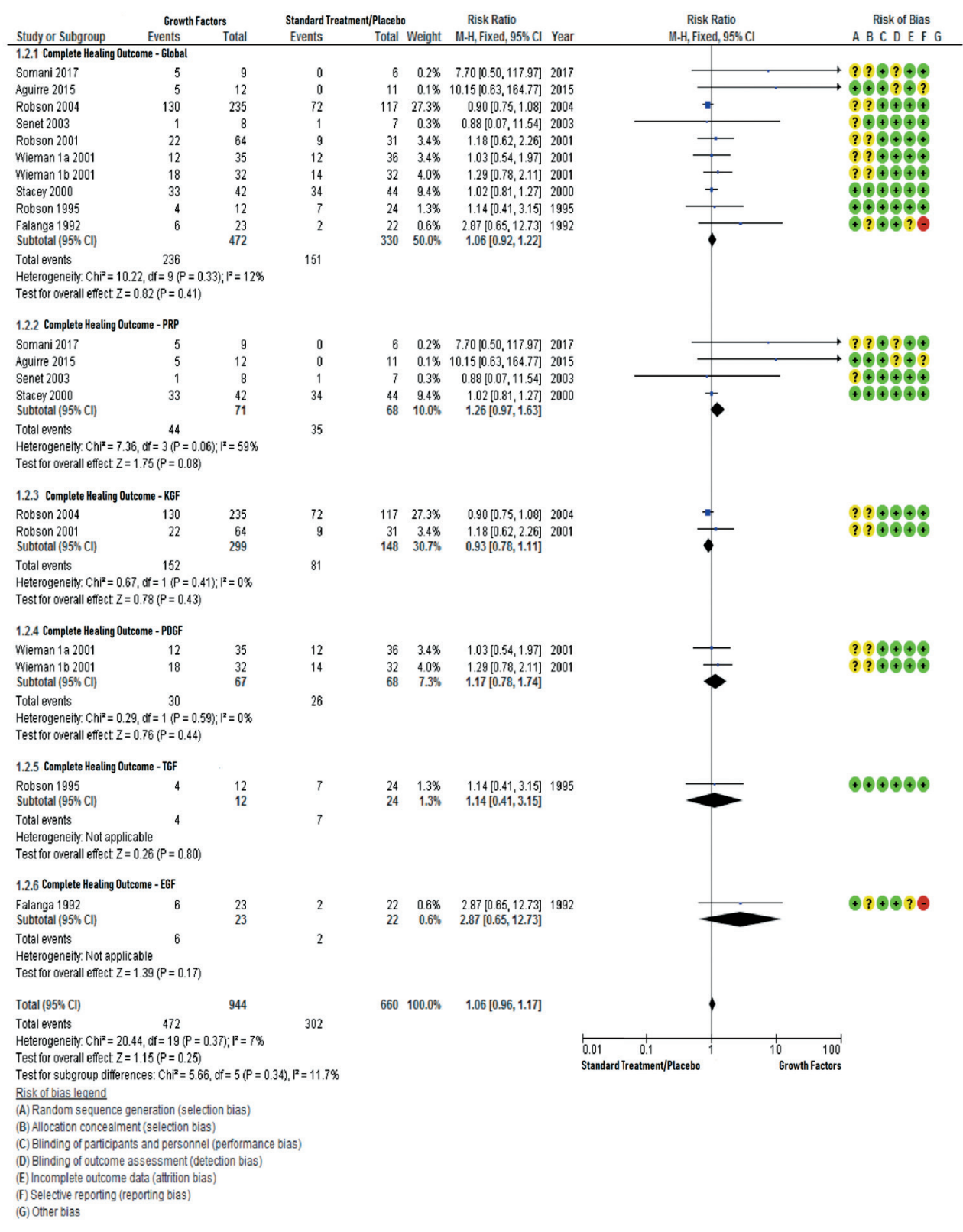

Note: Risk of bias: Green color: Low risk; Yellow color: Moderate risk; Red color: High risk of bias.

Figure 2 - Global and subgroup meta-analysis charts for comparative analysis of the occurrence of complete healing outcome in venous ulcers with growth factor versus standard treatment/placebo
The Summary of Results presents the classification of evidence according to the GRADE System (Chart 4).

\section{DISCUSSION}

It is known that the classification of evidence quality, according to the GRADE System, evaluates five domains, the first domain being the risk of bias of the studies involved. In this review, most studies were classified as moderate risk of bias, with the most frequent failure being to describe the method of randomization and/or secrecy of allocation used. In an attempt to improve the quality of the research reports, the CONSORT (Consolidated Standards of Reporting Trials) ${ }^{(27-28)}$. Every article resulting from a clinical trial must follow the recommendations described in the statement, which include details about the masking process, method of randomization and secrecy of allocation, among others ${ }^{(27-28)}$. Failure to comply with the recommendations inevitably leads to a reduction in the quality of the study's evidence and a real difficulty in interpreting the evidence found.

Chart 4 - Summary of Results presenting the relative risk, number of participants and quality of evidence for each decrease factor evaluated according to the GRADE System

\begin{tabular}{|c|c|c|c|}
\hline \multicolumn{5}{|c|}{ COMPARISON BETWEEN TREATMENT WITH GROWTH FACTORS OR STANDARD TREATMENT/PLACEBO } \\
FOR VENOUS ULCERS FOR COMPLETE HEALING OUTCOME
\end{tabular}




\begin{tabular}{|c|c|c|c|}
\hline \multicolumn{5}{|c|}{ COMPARISON BETWEEN TREATMENT WITH GROWTH FACTORS OR STANDARD TREATMENT/PLACEBO } \\
FOR VENOUS ULCERS FOR COMPLETE HEALING OUTCOME
\end{tabular}

Considering the data presented by the 10 studies analyzed, it was verified that the application of growth factors in venous ulcers presented favorable results in most of the studies, however, with little statistical relevance, small sample size and studies classified as moderate risk of bias. Therefore, the evidence generated must be interpreted with caution.

In view of this, ten studies were included in this review, four of them evaluated the action of Platelet-Rich Plasma ${ }^{(18-19,21,24)}$; the others evaluated recombinant growth factors ${ }^{(20,22-23,25-26)}$.

According to the year of publication of the studies, it is noticed that initially there was a greater emphasis in studies containing recombinant growth factors. From 2000, the studies that used Platelet-Rich Plasma as a primary source for the application of growth factors in venous ulcers. However, in the last decade, only 2 Randomized Clinical Trials ${ }^{(18-19)}$ were conducted. A hypothesis for the low production of RCTs could involve the little encouraging results obtained so far. Another issue could be related to the association of factors and growth to compression therapy, present in most studies. Compression therapy is already consecrated as a gold standard for the treatment of venous ulcers due to its effectiveness ${ }^{(29)}$. Therefore, it was expected that the ulcers presented good healing rates in both groups, which could explain the simple positive effect of growth factors on venous ulcers when compared to the promising results obtained in wounds of other etiologies.

Thus, when analyzing the forest plot, it was observed that the incidence of global complete healing was similar between the groups that received growth factors and the control group. The confidence intervals of all the studies analyzed and the diamond chart crossed the statistical null line indicating statistically insignificance of this result. However, it is important to emphasize that the groups that received treatment with any growth factor did not present inferior results to the control groups.

Four studies evaluated the use of PRP for the treatment of venous ulcers ${ }^{(18-19,21,24)}$.Thus, when analyzing the summary estimate regarding the treatment of venous ulcers using Platelet-Rich Plasma, there was a slight tendency to achieve complete healing in the group treated with PRP compared to the control group, however, without statistical relevance $(p=0.08)$. It is noteworthy that the studies presented small samples and were classified as moderate risk of bias. However, there is increasing interest in the tissue regenerative potential of PRP, several studies worldwide have reported positive results using PRP in chronic ulcers ${ }^{30-}$ ${ }^{31,33-34)}$.A non-randomized comparative study published in 2017 evaluated 40 participants with venous ulcers, evaluating the PRP associated with compression therapy for 6 weeks. The PRP group had significant wound area reduction rates $(p<0.0001)^{(34)}$. However, few Randomized Clinical Trials were reported using PRP for treatment of venous ulcers ${ }^{(31)}$.

Other reviews have evaluated the potential of PRP for the healing of chronic ulcers. A review published in 2011 included 4 Randomized Clinical Trials where Platelet-Rich Plasma was evaluated in chronic ulcers (mostly diabetic and pressure ulcer), the outcome for the complete healing outcome was significant in favor of PRP $(p=0.01)^{(11)}$. In contrast, a Cochrane review published in 2016 analyzed 8 Randomized Clinical Trials that also used PRP for leg ulcers (diabetic, venous and mixed etiologies), where it was found that there is insufficient evidence to safeguard the beneficial factor of PRP(10).

When analyzing the KGF applied in venous ulcers, it was observed that there was no beneficial effect for the complete healing outcome. The relative risk of venous ulcer healing completely with the use of KGF was 0.93, with no statistical significance. It is noted that the two studies analyzed were published by the same author who evaluated different doses of the drug in an attempt to establish an effective dosage. A review published in 2012 discussed on the potential of KGF for tissue regeneration ${ }^{(35)}$. The authors concluded that although KGF showed positive results in in vitro or animal models, the result was not replicated in clinical studies, causing a scientific disappointment and consequent discontinuation of some 
studies $^{(35)}$. In recent years, studies involving KGF have focused on the treatment of burns due to its anti-scar potential ${ }^{(36)}$.

Regarding PDGF, the two studies included in this analysis were conducted by the same research group, where the authors evaluated in one study the efficacy of recombinant PDGF at a dosage of $100 \mu \mathrm{m} / \mathrm{g}$ applied twice a week and in another study, your daily application $^{(22)}$. Analyzing the results of the meta-analysis, it was observed that there were no differences between the groups that received PDGF and control group for the complete healing outcome $(p=0.44)$. Other studies have already been carried out using PDGF for the treatment of chronic ulcers, but the results were not very encouraging ${ }^{(37-38)}$.

Only one study evaluated the efficacy of TGF for venous ulcers, the study evaluated 12 ulcers in the use of TGF-impregnated collagen based dressing; 12 in use of pure collagen matrix and 12 only with petrolatum gauzedressing ${ }^{(25)}$. The complete healing rate of TGF-treated ulcers was not higher than that of ulcers treated with collagen matrix or petrolatum gauze dressing $(p=0.80)$.Although TGF is a fundamental factor for wound healing, when there is an imbalance of this growth factor and its isomers an exacerbated scar formation can occur, increasing the chance of formation of hypertrophic scar and keloid ${ }^{(39-40)}$. Therefore, it is necessary to establish safely the ideal dosage that is capable of promoting a better scarring without exceeding in the formation of the scar.

Analyzing the EGF results in the forest plot, it is possible to observe that although it presents a relative risk of 2.87 in favor of the use of EGF this result is not significant $(p=0.17)$, besides being classified as low quality of evidence. It is worth remembering that this study was the only one that received the classification of high risk of bias due to incomplete data reporting. However, interest in this growth factor grows in the scientific community. A review of growth factors for treatment of chronic ulcers has reported that topically applied EGF, such as cream or even injected, has been studied by several research groups especially in Asia and $\mathrm{Cuba}^{(6)}$.Other studies using EGF in chronic ulcers reported positive results. A prospective study published in 2014 evaluated 33 venous ulcers treated with EGF embedded in a collagen-based dressing and found a significant beneficial EGF result ${ }^{(41)}$. Two clinical trials evaluated the successful regenerative potential of EGF in diabetic ulcers ${ }^{(42-43)}$. Therefore, the use of EGF seems to be an interesting and promising alternative for the treatment of chronic ulcers, such as venous etiology.

In the US, the only one approved by the Food and Drug Administration (FDA) for use in chronic ulcers to date was Becaplermin/ Regranex ${ }^{\circledast}$ (PDGF). EGF (Heberprot- ${ }^{\circledR}$ ) has been successfully used in Asia, Central and South America, expanding its worldwide acceptance to Europe, mainly for use in diabetic ulcers ${ }^{(6)}$. In Brazil, no growth factor has approval for use in wounds, as medicine, by the Brazilian Agency of Sanitary Surveillance (ANVISA - Agência Nacional de Vigilância Sanitária) until the present moment. This fact hinders the development of research to evaluate the efficacy of these recombinant growth factors in the Brazilian setting.

However, obtaining and preparing Platelet-Rich Plasma autologous has a relatively low degree of difficulty and has been shown to be safe in previous studies ${ }^{(30-31)}$. The preparation of the PRP does not require sophisticated equipment, with only a small centrifuge and the preparation material. Several techniques for obtaining PRP have been described in the literature ${ }^{(44-45)}$.However, there is a need for follow-up of a multiprofessional team, with the involvement of at least the medical professional and nurse to apply the technology safely.

Most of the studies included in the present review evaluated patients with chronic ulcers with evolution for less than 2 years. Demographic studies conducted in Brazil have shown that most of the Brazilian venous ulcers exceed 10 years of evolution ${ }^{(46-48)}$. In addition, the size of Brazilian venous ulcers easily surpasses the average found in the studies analyzed in the present review. A study, published in 2012 , showed that $39.2 \%$ of patients had ulcers over $24 \mathrm{~cm}^{2(46)}$.

Another aggravating factor in the Brazilian setting is the limited material resource found in the public health system. Despite the recommendation for using compression therapy as first-line treatment for venous ulcers, in practice, few patients have access to this technology. According to a study carried out in a public clinic in the Rio de Janeiro State, only $1.5 \%$ of patients use compression therapy ${ }^{(47)}$. A comparative study including 40 participants applied the autologous PRP in the test group and only the compression therapy in the control group, obtaining significant results $(p<0.05)$ favorable to PRP ${ }^{(34)}$. The application of autologous PRP in the Brazilian context where compression therapy does not present much scope, either due to a lack of material, financial resources or even intolerance by patients, may be a possibility of treatment.

However, further studies with methodological quality are needed to validate or not the application of growth factors for the treatment of venous ulcers in the Brazilian setting.

\section{Study limitations}

Although there was no restriction on the language of publication, it is understood that the search results may have failed to retrieve any potential study, mainly because it did not include bases outside the United States-Europe-Latin America axis. Another limiting factor of this review is the fact that the reviewers did not attempt to contact the authors of the included studies to clarify some items evaluated by the bias risk assessment instrument. The risk assessment of bias considered only the data available in the published material and in the respective protocols, when found. In addition, the present review evaluated only complete healing as an outcome, as this was the outcome most evaluated by the studies and easier homogenization in a meta-analysis. However, another review addressing other outcomes is already under way.

\section{Contributions for the sectors of Nursing, Health or Public Policy}

The present review provides recommendations for clinical practice on the use of growth factors in venous ulcers, supporting the decision making of both nurses and other professionals who wish to use this therapy in their patients.

There are recommendations for clinical practice, considering the application of growth factors as adjuvant therapy to compression therapy:

- The application of growth factors presented similar results in the complete healing of venous ulcers, compared to the 
control group (RR: 1.06 [95\% Cl 0.92-1.22, $\mathrm{p}=0.41$ ). Moderate quality of evidence.

- The application of Platelet-Rich Plasma presented a slight tendency to reach complete healing, however, without statistical relevance (RR 1.26 [95\% Cl 0.97-1.63], $\mathrm{p}=0.08$ ). Moderatequalityofevidence.

- The application of KGF, PDGF and TGF had no beneficial effect on the complete healing outcome (RR $0.93[95 \% \mathrm{Cl}$ 0.78-1.11), $p=0.43$ for KGF; RR 1.17 [95\% Cl 0.78-1.74], $p=0.44$ for PDGF and RR 1.14 [95\% Cl 0.41-3.15], $p=0.8$ for TGF). Moderate quality of evidence.

- The EGF application presented better complete healing rates, however without significant relevance (RR 2.87 [95\% $\mathrm{Cl} 0.65-12.73], p=0.17$.) Low quality of evidence.

\section{CONCLUSION}

Evidence on the application of growth factors to the treatment of venous ulcers is still limited. The relative effect of the application of growth factors to complete healing on venous ulcers is unclear. There was a slight tendency to achieve complete healing when applied to Platelet-Rich Plasma and Epidermal Growth Factor, however, these findings were not relevant $(p<0.05)$. However, most of the studies included in this analysis were classified as moderate risk of bias.

Thus, more robust studies, with greater power, higher methodological quality and greater casuistry are necessary to generate more precise recommendations on the use of growth factors for the treatment of venous ulcers.

\section{REFERENCES}

1. Eming SA, Martin P, Tomic-Canic M. Wound repair and regeneration: mechanisms, signaling, and translation. SciTransl Med [Internet]. 2014 [cited 2017 Jul 2];6(265):265sr6. Available from: http://dx.doi.org/10.1126/scitranslmed.3009337

2. Reinke JM, Sorg H. Wound repair and regeneration. Eur Surg Res [Internet]. 2012 [cited 2017 Jul 2];49:35-43. Available from: http://dx.doi. org/10.1159/000339613

3. Olszewer E, Arroyo E, Nakamura F. PRP-Plasma rico em plaquetas. 1 th ed. São Paulo: Editora Fapes Books; 2015. 308 p.

4. Dinh T, Braunagel S, Rosenblum BI. Growth factors in wound healing: the present and the future? Clin Podiatr Med Surg [Internet]. 2015 [cited 2017 Jul 2];32(1):109-19. Available from: http://dx.doi.org/10.1016/j.cpm.2014.09.010

5. Mendonça RJ de, Coutinho-Netto J. Cellular aspects of wound healing. An Bras Dermatol [Internet]. 2009 [cited 2017 Jul 2];84(3):257-62. Available from: http://dx.doi.org/10.1590/S0365-05962009000300007

6. Frykberg RG, Banks J. Challenges in the Treatment of Chronic Wounds. Adv Wound Care [Internet]. 2015 [cited 2017 Sep 5];4(9):560-82. Available from: http://dx.doi.org/10.1089/wound.2015.0635

7. Demidova-Rice TN, Hamblin MR, Herman IM. Acute and impaired wound healing: pathophysiology and current methods for drug delivery, part 2: role of growth factors in normal and pathological wound healing: therapeutic potential and methods of delivery. Adv Skin Wound Care [Internet]. 2012 [cited 2017 Sep 6];25(8):349-70. Available from: http://dx.doi.org/10.1097/01.ASW.0000418541.31366.a3

8. Bosanquet DC, Harding KG. Wound duration and healing rates: cause or effect? Wound Repair Regen [Internet]. 2014 [cited 2017 Sep 05];22(2):143-50. Available from: http://dx.doi.org/10.1111/wrr.12149

9. Agale SV. Chronic leg ulcers: epidemiology, aetiopathogenesis, and management. Ulcers [Internet]. 2013 [cited 2017 Nov 9];2013:e413604. Available from: http://dx.doi.org/10.1155/2013/413604

10. Martinez-Zapata MJ, Martí-Carvajal AJ, Solà I, Expósito JA, Bolíbar I, Rodríguez L, et al. Autologous platelet-rich plasma for treating chronic wounds. Cochrane Database Syst Rev [Internet]. 2016 [cited 2017 Sep 5];(5):CD006899. Available from: http://dx.doi.org/10.1002/14651858. CD006899.pub3

11. Carter MJ, Fylling CP, Parnell LKS. Use of Platelet Rich Plasma Gel on Wound Healing: A Systematic Review and Meta-Analysis. Eplasty [Internet]. 2011 [ cited 2017 Set 6];11:e38. Available from: https://www.ncbi.nlm.nih.gov/pmc/articles/PMC3174862/

12. Villela DL, Santos VLCG. Evidence on the use of platelet-rich plasma for diabetic ulcer: a systematic review. Growth Factors [Internet]. 2010[cited 2017 Sep 6];28(2):111-6. Available from: http://dx.doi.org/10.3109/08977190903468185

13. He JD, Ouyang XB, Zhang L, Yang XR, Wu QR. Autologous platelet-rich gel for diabetic foot ulcer: a systematic review of randomized controlled trials. Chinese Journal of Evidence-Based Medicine [Internet]. 2010 [cited 2017 Sep 6];10(7):838-41. Available from: https://www. ncbi.nlm.nih.gov/books/NBK79817/

14. Higgins JP, Green S, editors. Cochrane handbook for systematic reviews of interventions [Internet]. Version 5.1.0 Chichester (UK): John Wiley \& Sons, Ltd.; 2006 [updated Sep 2011; cited 2017 Sep 10]. 257 p. Available from: http://www.cochrane.org/resources/handbook/handbook.pdf

15. Santos CM da C, Pimenta CA de M, Nobre MRC. The PICO strategy for the research question construction and evidence search. Rev Lat Am Enferm [Internet]. 2007 [cited 2017 Sep 10];15(3):508-11. Available from: http://dx.doi.org/10.1590/S0104-11692007000300023

16. Mani R, Romanelli M, Shukla V, editors. Measurements in wound healing: Science and Practice. London: Springer-Verlag; 2012.361 p.

17. Galvão TF, Pereira MG. [Rating the quality of evidence of systematic reviews]. Epidemiol Serv Saúde [Internet]. 2015 [cited 2017 Nov 03];24(1):173-175. Available from: http://dx.doi.org/10.5123/S1679-49742015000100019 Portuguese 
18. Somani A, Rai R. Comparison of Efficacy of Autologous Platelet-rich Fibrin versus Saline Dressing in Chronic Venous Leg Ulcers: A Randomised Controlled Trial. J Cutan Aesthet Surg [Internet]. 2017 [cited 2017 Oct 15];10(1):8-12. Available from: http://dx.doi.org/10.4103/ JCAS.JCAS_137_16

19. Aguirre JJ, Anitua E., Francisco S, Cabezas Al, Orive G, Algorta J. Efficacy and safety of plasma rich in growth factors in the treatment of venous ulcers: a randomized clinical trial controlled with conventional treatment. Clinical Dermatology [Internet]. 2015 [cited 2017 Oct 15];3(1):13-20. Available from: https://www.clinicaldermatology.eu/materiale_cic/816_3_1/6983_efficacy/article.htm

20. Robson M, Hanfnt J, Garner W, Jenson J, Serena T, Payne WG, et al. Healing of Chronic Venous Ulcers Is Not Enhanced by the Addition of Topical Repifermin (KGF-2) to standardized Care. J Appl Res [Internet]. 2004 [cited 2017 Oct 15];4(2):302-11. Available from: http://www. jrnlappliedresearch.com/articles/Vol4lss2/robson-Jar-spring.pdf

21. Senet P, Bon F-X, Benbunan M, Bussel A, Traineau R, Calvo F, et al. Randomized trial and local biological effect of autologous platelets used as adjuvant therapy for chronic venous leg ulcers. J Vasc Surg [Internet]. 2003 [cited 2017 Oct 15];38(6):1342-8. Available from: http://dx.doi. org/10.1016/S0741-5214(03)00908-X

22. Wieman TJ. Efficacy and Safety of Recombinant Human Platelet-Derived Growth Factor-BB (Becaplermin) in Patients with Chronic Venous Ulcers. Wounds [Internet]. 2003 [cited 2017 Oct 15];15(9):257-64. Available from: http://www.woundsresearch.com/article/1931

23. Robson MC, Phillips TJ, Falanga V, Odenheimer DJ, Parish LC, Jensen JL, et al. Randomized trial of topically applied repifermin (recombinant human keratinocyte growth factor-2) to accelerate wound healing in venous ulcers. Wound Repair Regen [Internet]. 2001 [cited 2017 Oct 15];9(5):347-52. Available from: http://dx.doi.org/10.1046/j.1524-475x.2001.00347.x

24. Stacey MC, Mata SD, Trengove NJ, Mather CA. Randomised double-blind placebo controlled trial of topical autologous platelet lysate in venous ulcer healing. Eur J Vasc Endovasc Surg [Internet] 2000 [cited 2017 Oct 15];20(3):296-301. Available from: http://dx.doi.org/10.1053/ ejvs.2000.1134

25. Robson MC, Phillip LG, Cooper DM, Lyle WG, Robson LE, Odom L, et al. Safety and effect of transforming growth factor- $\beta 2$ for treatment of venous stasis ulcers. Wound Repair Regen [Internet]. 1995 [cited 2017 Oct 15];3(2):157-67. Available from: http://dx.doi. org/10.1046/j.1524-475X.1995.30207.x

26. Falanga V, Eaglstein WH, Bucalo B, Katz MH, Harris B, Carson P. Topical use of human recombinant epidermal growth factor (h-EGF) in venous ulcers. J Dermatol Surg Oncol. 1992;18(7):604-6.

27. Schulz KF, Altman DG, Moher D, for the CONSORT Group. CONSORT 2010 Statement: updated guidelines for reporting parallel group randomised trials. Int J Surg [Internet]. 2011 [cited 2017 Nov 15];9(8):672-7. Available from: http://dx.doi.org/10.1016/j.ijsu.2011.09.004

28. Moher D, Hopewell S, Schulz KF, Montori V, Gøtzsche PC, Devereaux PJ, Elbourne D, Egger M, Altman DG. CONSORT 2010 explanation and elaboration: updated guidelines for reporting parallel group randomised trials. Int J Surg [Internet]. 2012 [cited 2017 Nov 15];10(1):28-55. Available from: http://dx.doi.org/10.1016/j.ijsu.2011.10.001

29. De Carvalho MR, Silveira, IA, Abreu AM, Ribeiro APL, Peixoto BU, Oliveira BGR. All about compression: a literature review. J Vasc Nurs [Internet]. 2016 [cited 2017 Nov 02];34(2):47-53. Available from: https://doi.org/10.1016/j.jvn.2015.12.005

30. Obolenskiy VN, Ermolova DA, Laberko LA, Semenova, TV. Efficacy of platelet-rich plasma for the treatment of chronic wounds. EWMA Journal [Internet]. 2014 [cited 2018 Nov 03];14(1):37-41. Available from: http://old.ewma.org/fileadmin/user_upload/EWMA/pdf/journals/ Scientific_articles/Articles_April_2014/Journal_1_2014_Obolensky_WEB.pdf

31. Sarvajnamurthy S, Suryanarayan S, Budamakuntala L, Suresh DH. Autologous Platelet Rich Plasma in Chronic Venous Ulcers: Study of 17 Cases. J Cutan Aesthet Surg [Internet]. 2013 [cited 2017 Oct 28];6(2):97-9. Available from: http://dx.doi.org/10.4103/0974-2077.112671

32. Shan GQ, Zhang YN, Ma J, Li YH, Zuo DM, Qiu JL, Cheng B, Chen ZL. Evaluation of the effects of homologous platelet gel on healing lower extremity wounds in patients with diabetes. Int J Low Extrem Wounds [Internet]. 2013 [cited 2017 Nov 03];12(1):22-9. Available from: http:// dx.doi.org/10.1177/1534734613477113

33. Suthar M, Gupta S, Bukhari S, Ponemone V. Treatment of chronic non-healing ulcers using autologous platelet rich plasma: a case series. J Biomed Sci [Internet]. 2017 [cited 2017 Nov 03];24(1):16. Available from: http://dx.doi.org/10.1186/s12929-017-0324-1

34. Moneib HA, Youssef SS, Aly DG, Rizk MA. Abdelhakeen YI. Autologous platelet-rich plasma versus convencional therapy for the treatment of chronic venous leg ulcer: A comparative study. J Cosmet Dermatol. 2018;17(3):495-501. doi: 10.1111/jocd.12401

35. Plichta JK, Radek KA. Sugar-coating wound repair: A review of FGF-10 and dermatan sulfate in wound healing and their potential application in burn wounds. J Burn Care Res [Internet]. 2012 [cited 2017 Nov 13];33(3):299-310. Available from: http://dx.doi.org/10.1097/ BCR.0b013e318240540a

36. Akita S, Akino K, Hirano A. Basic Fibroblast Growth Factor in Scarless Wound Healing. Adv Wound Care (New Rochelle) [Internet]. 2013 [cited 2017 Nov 05];2(2):44-49. Available from: http://dx.doi.org/10.1089/wound.2011.0324

37. Senet P, Vicaut E, Beneton N, Debure C, Lok C, Chosidow O. Topical treatment of hypertensive leg ulcers with platelet-derived growth factor-bb: A randomized controlled trial. Arch Dermatol [Internet]. 2011 [cited 2017 Nov 6];147(8):926-30. Available from: http://dx.doi. org/10.1001/archdermatol.2011.84

38. Ma C, Hernandez MA, Kirkpatrick VE, Liang LJ, Nouvong AL, Gordon II.Topical platelet-derived growth factor vs placebo therapy of diabetic foot ulcers offloaded with windowed casts: a randomized, controlled trial. Wounds. 2015;27(4):83-91.

39. Finnson KW, McLean S, Di Guglielmo GM, Philip A. Dynamics of Transforming Growth Factor Beta Signaling in Wound Healing and 
Scarring. Adv Wound Care (New Rochelle) [Internet]. 2013 [cited 2017 Nov 9];2(5):195-214.Available from: http://dx.doi.org/10.1089/ wound.2013.0429

40. Pakyari M, Farrokhi A, Maharlooei MK, GhaharyA. Critical Role of Transforming Growth Factor Beta in Different Phases of Wound Healing. Adv Wound Care (New Rochelle) [Internet]. 2013 [cited 2017 Nov 16];2(5):215-224. Available from: http://dx.doi.org/10.1089/ wound.2012.0406

41. Doerler M, Eming S, Dissemond J, Wolter A, Stoffels-Weindorf M, Reich-Schupke S. et al. A Novel Epidermal Growth Factor-Containing Wound Dressing for the Treatment of Hard-to-Heal Venous Leg Ulcers. Adv Skin Wound Care [Internet]. 2014 [cited 2017 Nov 7];27(10):45660. Available from: http://dx.doi.org/10.1097/01.ASW.0000451942.39446.c2

42. Gomez-Villa R, Aguilar-Rebolledo F, Lozano-Platonoff A, Teran-Soto JM, Fabian-Victoriano MR, Kresch-Tronik NS, et al. Efficacy of intralesional recombinant human epidermal growth factor in diabetic foot ulcers in Mexican patients: a randomized double-blinded controlled trial. Wound Repair Regen [Internet]. 2014 [cited 2017 Nov 5];22(4):497-503. Available from: http://dx.doi.org/10.1111/wrr.12187

43. Dumantepe M, Fazliogullari O, Seren M, Uyar I, BasarF.Efficacy of intralesional recombinant human epidermal growth factor in chronic diabetic foot ulcers. Growth Factors [Internet]. 2015 [cited 2017 Nov 04];33(2):128-32. Available from: http://dx.doi. org/10.3109/08977194.2015.1031898

44. Vendramin, FS, Franco D, Franco, TR. Methods to obtain autologous platelet-rich plasma gel. Rev Bras Cir Plast [Internet]. 2009 [cited 2018 Nov 03;24(2):212-8. Available from: http://www.rbcp.org.br/details/471/en-US/methods-to-obtain-autologous-platelet-rich-plasma-gel

45. Dhurat R, Sukesh M. Principles and Methods of Preparation of Platelet-Rich Plasma: A Review and Author's Perspective. J Cutan Aesthet Surg [Internet]. 2014 [cited 2018 Nov 03];7(4):189-197. Available from: http://dx.doi.org/10.4103/0974-2077.150734

46. Sant'Ana SMSC, Bachion MM, Santos QR, Nunes CAB, Malaquias SG, Oliveira BGRB. [Venous ulcers: clinical characterization and treatment in users treated in outpatient facilities]. Rev Bras Enferm [Internet]. 2012 [cited 2018 May 04];65(4):637-644. Available from: http://dx.doi. org/10.1590/S0034-71672012000400013 Portuguese.

47. Oliveira B, Nogueira G, Carvalho MR, Abreu A. [The characterization of patients with venous ulcer followed at the Outpatient Wound Repair Clinic]. Rev Eletr Enf [Internet]. 2012 [cited 2018 May 04];14(1):156-63. Available from: https://doi.org/10.5216/ree.v14i1.10322 Portuguese.

48. Eberhardt T, Lima S, Lopes L, Gracióli J, Fonseca G, Ribeiro L. [Sociodemographic and clinical profile of patients with Venous ulcers in outpatient follow-up: descriptive cross-sectional study]. Rev Enferm UFSM. 2016 [cited 2018 May 04];6(4):539-47. Available from: http:// dx.doi.org/10.5902/2179769223054 Portuguese. 